\title{
'He heals the brokenhearted and binds up their wounds' (Ps 147:3): Perspectives on pastoral care
}

\begin{tabular}{|c|c|}
\hline \multicolumn{2}{|c|}{$\begin{array}{l}\text { Author: } \\
\text { Werner R.A. Klän }{ }^{1,2} \text { (D) }\end{array}$} \\
\hline \multicolumn{2}{|c|}{$\begin{array}{l}\text { Affiliations: } \\
{ }^{1} \text { Lutheran Theological } \\
\text { Seminary, Oberursel, } \\
\text { Germany }\end{array}$} \\
\hline \multicolumn{2}{|c|}{$\begin{array}{l}{ }^{2} \text { Department of Church } \\
\text { History and Church Polity, } \\
\text { Faculty of Theology and } \\
\text { Religion, University of } \\
\text { Pretoria, South Africa }\end{array}$} \\
\hline \multicolumn{2}{|c|}{$\begin{array}{l}\text { Research Project Registration: } \\
\text { Project Leader: J. Pillay (D } \\
\text { Project Number: } 04653484\end{array}$} \\
\hline \multicolumn{2}{|c|}{$\begin{array}{l}\text { Description: } \\
\text { This research is part of the } \\
\text { project 'African Christianity } \\
\text { and Development,' directed } \\
\text { by Prof. Dr Jerry Pillay, } \\
\text { Department of Church } \\
\text { History and Church Polity, } \\
\text { Faculty of Theology, } \\
\text { University of Pretoria. }\end{array}$} \\
\hline \multicolumn{2}{|c|}{$\begin{array}{l}\text { Corresponding author: } \\
\text { Werner Klän, } \\
\text { werner.klaen@gmx.de }\end{array}$} \\
\hline \multicolumn{2}{|c|}{$\begin{array}{l}\text { Dates: } \\
\text { Received: } 21 \text { May } 2018 \\
\text { Accepted: } 16 \text { Aug. } 2018 \\
\text { Published: } 30 \text { Oct. } 2018\end{array}$} \\
\hline \multicolumn{2}{|c|}{$\begin{array}{l}\text { How to cite this article: } \\
\text { Klän, W.R.A., 2018, "“He heals } \\
\text { the brokenhearted and binds } \\
\text { up their wounds" (Ps 147:3): } \\
\text { Perspectives on pastoral } \\
\text { care', HTS Teologiese Studies/ } \\
\text { Theological Studies 74(4), } \\
\text { a5116. https://doi.org/ } \\
\text { 10.4102/hts.v74i4.5116 }\end{array}$} \\
\hline \multicolumn{2}{|l|}{ Read online: } \\
\hline 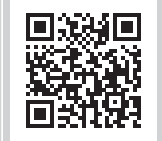 & $\begin{array}{l}\text { Scan this QR } \\
\text { code with your } \\
\text { smart phone or } \\
\text { mobile device } \\
\text { to read online. }\end{array}$ \\
\hline
\end{tabular}

The psalmist is deeply convinced that God is a reliable addressee to whom those hurt, traumatised and grieving may turn. Churches, by their mandate to share God's lovingkindness, are obliged to provide opportunities, counselling and pastoral care to those who suffer from violations in their lives. Representatives of the church will do so by proclaiming God's compassion and pitifulness. This obligation is all the more important as it can be observed that Christians, congregations and churches have oftentimes been part and parcel of processes that caused harm, hurt and trauma to their members or other people.

\section{Preliminary remarks: Trauma}

Dealing with hurt and grief means for pastors and churches to enter into the field of pastoral care, or into the scholarly realm of poimenics. Treating pastoral care from a Christian point of view is understood in this venerable synodical convention. That is why we will have to consult biblicaltheological insights and from the area of the Lutheran Confessions. However, this does not preclude results from history and psychology as well; for such may help us to contextualise our theological findings in our time and context.

'Hurt' and 'grief' are synonyms for what historians and psychologists label 'trauma'. The Greek word literally means 'wound'. In this sense it is still used in medical science. Derived from this meaning we find a variety of definitions in the field of psychology and, transferred from there, also in historical science. According to the Diagnostic and Statistical Manual of Mental Disorders, 5th Edition, trauma is defined as an event where an individual person is exposed to actual or threatened death, serious injury, or sexual violence' (American Psychiatric Association [APA] 2013:271). In terms of groups of people, societies or churches, one has to acknowledge the concept of 'historical trauma':

Historical trauma refers to trauma inflicted in the past on members of a certain cultural group that may
continue to have effects on the current generation. The concept was originally developed to help explain
how generations descended from Holocaust survivors continued to be psychologically affected by the
trauma their parents and /or grandparents had experienced. (Duran \& Duran 1995, passim; Sotero 2006,
passim) '[...] Other groups who experienced large-scale and well-remembered violence, such as attempted genocide or slavery, also have to deal with historical trauma' (Sotero 2006:93).

Events that may cause trauma are manifold. Whether or not such an event can be seen as traumatic depends on the way a given individual experiences it, that is to say, how he or she 'labels, assigns meaning to, and is disrupted' (Substance Abuse and Mental Health Services Administration [SAMHSA] 2014:8) by the event. And the - sometimes long-lasting - effects of this event are then the result of that very experience. In a therapy, all the individual circumstances and determining factors will have to be taken into account.

There are various symptoms of such emotional trauma; in any case:

$[t]$ rauma results from an event, series of events, or set of circumstances that is experienced by an individual as physically or emotionally harmful or threatening and that has lasting adverse effects on the individual's functioning and physical, social, emotional, or spiritual well-being. (SAMHSA, Trauma and Justice Strategic Initiative 2014:2)

Note: Keynote Address to the 60th Synodical Convention of the Free Evangelical-Lutheran Synod in South Africa, Christ-Church, Kirchdorf, Wartburg, 09 September 2016

Copyright: () 2018. The Authors. Licensee: AOSIS. This work is licensed under the Creative Commons Attribution License. 
Beyond that, we have to learn that even 'individual trauma occurs in a context of community' (SAMHSA 2014:17), be it an ethnicity, a neighbourhood, a school, a congregation or a church. Thus, the reactions coming from the community influence the way an individual deals with his or her traumatic event, its experience and its effects. In 'a context of understanding and support' (SAMHSA 2014:17) the traumatised person is likely to be helped in facilitating 'the healing and recovery process' (SAMHSA 2014:17). On the other hand, if the impact of trauma is avoided, overlooked or misunderstood, 'individuals can be retraumatized' (SAMHSA 2014:17).

\section{Pastoral care of the grieving}

From a sociopsychological point of view, healing of traumatic experiences and their effects may take place by ' $[m]$ aking sense of the trauma experience and telling the story of what happened using the language and framework of the community'; this might be 'an important step toward healing community trauma' (SAMHSA 2014:17). Historians and psychologists, in all these cases, see major difficulties in addressing the topic of 'guilt' (Bode 2011:268). Do we as Christians and as church have an answer beyond a sociopsychological perspective by taking the theological perception of the conditio humana seriously - that is, a relationship, albeit a broken relationship of human beings and God? Does the church have strategies of healing the psychological outcome of hurtful experiences? An answer to this question may be found in Luther's approach to the Godhuman relationship.

Let us first have a look at Luther's conceptualisation of the God-human relationship: Luther understands God as being God in relation to his human creatures. In accordance with biblical findings, Luther sees an unfolding of God's story in this relationship, a story that plays out in space and time - in other words, in history, even human life (Kolb 2012:2, fn. 9). When we presuppose that God really accompanies human beings in their lives and history, we find the connection to ourselves as being involved in God's history with humankind - rather than him being involved in our lives and history. For if God's revelation comes to completion in history, as it is portrayed in the Bible from creation to Christ's return for judgement, then human history including all its phenomena, not least trauma and grieving, is also included (Kolb 2012:6-7).

This corresponds with the communicative reality of God himself, as the God of the Bible speaks. This reality is found compacted in God's Word, the Logos made flesh, Jesus Christ: he takes upon himself the human fate with all its burdens, and in the end, by his suffering on the cross, restores the relationship that human rebellion has destroyed (Kolb \& Arand 2008:166, fn. 137).

In Christ we can perceive God's compassion with the human predicament. This is especially true in light of the fact that God's chosen people constantly were, are and remain helpless, faced with powers hostile to God and detrimental to human existence throughout history and in the course of human life (Kolb 2012:99-123). The history of the world is also the battlefield in God's fight against the devil's attempts to hollow out God's majesty, and the life of God's people is no less so. Suffering is therefore an inevitable part of a Christian's daily life (Kolb 2012:117-122). Grief is the companion to those who suffer, be it from their own wrongdoing or be it from violating actions of others.

Pastoral care in a biblical understanding and carried out by and within the church has, in the first place, to take into account the condition of sinfulness in all human beings and the merciful, selfless, helpful and salutary action taken by God to change this situation for the better for his beloved children. This approach distinguishes pastoral care from all non-Christian kinds of counselling (Rolf 2003:4). With such a deep understanding of sin as the condition of human beings in their relationship to God and one another, pastoral care will strive for a reassurance of God being mercifully close to the sinner rather than imposing a request to fulfil God's commands. The reality of sin is matched by the necessity to speak about God's wrath: God does not relativise sin and its effects as though he would simply exert an all-encompassing friendliness (Rolf 2003:4).

By contrast, Oswald Bayer understands and posits the Gospel from a Lutheran perspective and strictly as a 'categorical gift' for which there exists 'no human disposition': 'Gospel means: God speaks for me in the fragmentation of the time and dissipation of identities' (Bayer 2005:307; Rolf 2003:152). Christologically formulated this means that only 'on the strength of the incarnation of Jesus Christ my identity is reassigned to me'. This means that 'one receives a new excentrical [sic] - identity', which occurs 'in faith that is founded on the authoritative Word of the Gospel' to be helpful and salutary (Bayer 2005:309).

Only in this way, a sinner who has come to believe can become confident knowing that his or her life lies beyond his or her power of disposition. This foundational insight into the relationship between God and human beings applies also to situations of sorrow, trouble, hurt, grief and affliction. Oftentimes, people look for the meaningfulness of their suffering, hoping by discovering its significance to be able to cope with the challenges and the dreadful experiences they are facing (Rolf 2003:132-138).

Searching for the 'meaning' of harm and distress leaves the person with him- or herself. Nonetheless, there is space for trying to understand the conditions, circumstances and consequences of what a person has suffered or is suffering. This can indeed be helpful in order to penetrate the fate not understood to date - at least in part (Gobodo-Madikizela, Van der Merwe, passim). However, we can clearly indicate the limits of such attempts: A mere cognitive answer to those sometimes desperate, yet probing, questions will never suffice. If human existence in terms of its success were granted and guaranteed only by such self-contained 
analysis, then breakages would still remain: unsolved problems, unresolved difficulties and hurtful remnants (O'Loughlin 2015).

Therefore, pastoral care and Christian counselling will offer divine consolation in that God promises in Christ to be with us, at our side and on our side, even and especially in the midst of our afflictions (Kolb, 2010, passim) The Psalms of lament appeal to God, who seems to hide from the hurt, grief and sorrow of his people (Ps 5:3; 13:4; 69:2; 31:13; 42-43; $88: 15)$. Job even curses the day of his birth in view of the hopelessness of his situation while God keeps silent (Job 3:3.11; 30:20f.). 'Lament directed to God is always related to some past and future praise' (Bayer 2002:218). That is why the Psalms provide objections against the experience of distress and the feeling of godforsakenness: God is addressed as 'my shepherd' (Ps 23:1), 'my strength' (Ps 22:19), 'my light and my salvation' (Ps 27:1), 'our refuge and strength' (Ps 46:1), and 'my refuge and my fortress' (Ps 91:2). 'You are with me' (Ps 23:4) is the epitome of God's comfort and the consolation granted by him alone.

Such an existential relationship, particularly between God and his human creatures, comes into being particularly in confession and penitence (Peters 1994:51-53). The prerequisite is God's 'self-less' action, in which he shows the conscience how much it forgets God, how far away it is from God, how estranged and how godless the sinner's existence is and therefore how prone to wrath and threatened with death (eds. Kolb \& Wengert 2000:195 [Ap XII 51]). This threat is not the purpose; much more than that, it serves God's 'proper' work that grants life and speaks comfort (ed. Dingel 2014:450-453). ${ }^{1}$ The threat of God's wrath, as real as it is, only fulfils the purpose of creating space for God's manner of granting comfort and life (ed. Dingel 2014:450-453). ${ }^{2}$

That is what pastoral care has to convey to the afflicted (Rolf 2003:137f.). This consolatory approach transcends all strategies of self-assurance by opening up a wider space, namely a speech area in which despair, fear, grief and anger may be articulated, and beyond that also gratitude and joy (Rolf 2003:167). Those in pastoral care will be well aware of the fact that the need and want for consolation result from experiencing losses, instability and even the abysmal endangerment of human existence (Rolf 2003:174-176).

Against this, consolation functions in that it supplies the afflicted with the promise of God's benevolent closeness. For he is:

the Father of compassion and God of all comfort, who comforts us in all our troubles, so that we can comfort those in any trouble with the comfort we ourselves have received from God. (2 Cor $1: 3-4)$

In this way, pastoral care and Christian counselling is conducted by 'wounded healers' (Rolf 2003:168-171), who

1.Allienum est opus eius, ut operetur opus suum. Alienum opus Dei vocat, cum terret, quia Dei proprium opus est vivificare et consolari.

2.Verum ideo terret, inquit, ut sit locus consolationi et vivificationi. themselves are qualified for counselling by being connected to their very experiences of misery, doubt, affliction and helplessness.

Martin Luther knew quite well about afflictions and in the light of faith came to understand that 'God both loves and hates our afflictions. He loves them when they provoke us to prayer. He hates them when we are driven to despair by them' (ed. Tappert 1955:87). That is why Luther encourages his companions to firmly rely on God and his promises whenever temptation arises (Pless 2013:60). However, such advice is not spoken in a vacuum. Rather it is accompanied by 'personal advocacy for particular people in challenging circumstances' (Pless 2013:83). Luther definitely shows 'empathy for the persecuted and imprisoned' (Pless 2013:85-87).

\section{Scaer (1983) has underscored that:}

... Luther provides a precise and hence practical answer for the Christian caught in the affliction of knowing only a God of wrath. The Reformer directs these words to Christians who judge from outward appearances that God is treating them as though they were not His children: 'To be sure, public calamities hit saints and prophets, too, but not as happens in the case of the godless and ungrateful - out of wrath and punishment for them, but for their salvation, to test and to try their faith, love and patience, that the godly may learn to bear patiently the hand of God in His government'. (pp. 15-30)

John Pless has shown that 'Luther does not attempt to trivialize the pain nor does he offer stoic-sounding advice to endure detached from the reality of one's situation' (Pless 2013:49). This reality and the message derived from it make the counsellor 'speak of and to the reality that human beings are not autonomous but creatures bound to the earth by birth and death' (Pless 2013:105). However, sickness and the reality of death cry for consolation when bodily afflictions touch the soul at the same time (Pless 2013:90f.). It is the image of Christ crucified that people in those moments should meditate on. For he is the one to bestow 'upon us His righteousness and glory' by virtue of his resurrection (Pless 2013:101).

In the light of God's compassion as shown in Christ's fate, pastoral care of the grieving contradicts the reality of death in the midst of life (Pless 2013:109-118). Certainly, death, and the sudden death of a beloved in particular, is apt to shake even the believer's trust in God (Pless 2013:111). In such situations, Luther asks his addressees to reflect upon the gift that this special person had been to them. At the same time Luther acknowledges the mourning of those bereaved with compassion but counsels that they should 'not wallow in their loss' (Pless 2013:112). Rather they are advised 'to take refuge in God's gracious promise' that death 'brings the Christian's baptism to its divinely appointed consummation' (Pless 2013:114, 119-130). Baptism as God's work, and thus a 'treasure that God gives us and faith grasps' (eds. Kolb \& Wengert 2000:461 [LC IV 37]), is the location where all of Christ's gifts have been bestowed upon us, all his righteousness and holiness; there, our 'stricken conscience' finds 'the consolation of God's favor' (Pless 2013:127). 
In the course of our lifetime, we as Christians are allowed, invited and even urged by God himself to return to this starting point over and over again. This happens on a daily basis in repentance. What this means in terms of dealing with the reality of sin and its consequences in our lives - and hurt and grief are part and parcel of these realities - may well be illustrated by 2 of the 95 theses published by Martin Luther in 1517:

1. When our Lord and Master Jesus Christ said, 'Repent' [Mt 4:17], he willed the entire life of believers to be one of repentance. [...] 62. The true treasure of the church is the most holy gospel of the glory and grace of God. (eds. Grimm \& Lehmann 1957:25, 31)

Therefore, the church must never be found wanting in proclaiming the declaration of forgiveness and the salvation in Christ, seeing that it is a matter of 'comforting and consoling' those that are frightened and 'fainthearted' (Kolb \& Wengert 2000:584 [FC SD V 12]).

\section{Heritage of a dreadful past - Exemplifications from recent German history}

Trauma can be passed across generations. This, then, is labelled 'historical' or 'transgenerational' trauma (Schwab 2010:1-40) or even 'societal' trauma (Volkan 2009:1-26).

In order to illustrate observations concerning historical trauma, I will cite some results of research dealing with war and post-war traumata in the recent history of Germany. Although this report discusses a different time and context than South Africa in the beginning of the 21st century, namely findings from Second World War and post-war experiences in (western) Germany, it might mirror some of the experiences that people have gathered in their lives, in South Africa, in the history of the last 70 years and in the post-apartheid period, as atrocities, violence, killing, losses or fear of losses might be seen on the surface, or felt way underneath the surface. In post-World War II (western) Germany, the effort and results in the 'Wirtschaftswunder [economic growth]' era seemed to cover the traumatic experiences of war times and post-war deficiencies. However, just in this way, the healing of injuries to the souls of people was impeded as the memory of evil experiences was simply suppressed.

Just to make it as clear as possible right from the outset: I am not moaning about the fate of the German people by the end and after World War II. For the most part, the hardship that the defeated population had to suffer was nothing but a consequence to the godless and inhuman ideology of 'National Socialism' and a criminal war that arose from the hubris of a totalitarian, un-Christian political system. I am not trying to counterbalance one harm with another. I am not aiming at strategies of exculpation by pointing to the wrongs that the victorious powers may have done, and did do. The historical guilt that the people of Germany are responsible for cannot be reduced or minimised by the measures, be they legal or illegal, that the victorious Allies imposed on the defeated people, not even by outrageous injustice that happened.

\section{The 'forgotten generation' of the Second World War}

For those who were children by the time of World War II in Germany, many felt that what they experienced was 'normal' (Bode 2004:15). On the other hand, to the 'children of war', the past was omnipresent, for example, in the ruins of the destroyed cities across the country, and a strange taboo at the same time (Bode 2004:16). Questions asked to the older generation were refused and remained unanswered (Bode 2004:17). Even to themselves, they very often suppressed the memory of hunger, losses and other hardships they and their children went through. Instead they imagined that, at least the children, 'had been lacking nothing' (Bode 2004:97).

A little different is the fate of those who suffered flight and expulsion, like millions of Germans from the eastern territories like Prussia, Pomerania and Silesia. My mother's family counts among those refugees who, by the end of 1944, were sent out from Insterburg in East Prussia, enduring innumerable strains in the ice-cold weather, being overrun by the Red Army several times, with all those appalling concomitants that you wish nobody in all the world should undergo (which is, that I am well aware of, nothing but wishful thinking, as we see in South Sudan, Nigeria, Syria, Ukraine and elsewhere). For decades those circumstances of their flight remained unmentioned; my grandmother, my mother, the aunts, all of them maintained silence over what had befallen them. Of those, my mother was able to speak to her sons only as an elderly woman.

These refugee families had lost their homes, their money, their social network, their speech community - in the western parts of Germany they were easily identified as strangers by the dialect they spoke. Children therefore were raised to quickly assimilate into the new environment. Achievement-oriented standards were applied to the goals of education and advancement. The worst thing for those war children in their relationship with the parents was to cause disappointment (Bode 2004:113). Not to mention those children who lost both their parents and had to lead the life of an orphan. However, the German people for the most part had to continue with their lives in ruins, struggling to survive hunger, cold, hard winters and, if possible at all, fighting to earn their living.

What is new in this? It is not the harms and atrocities of the end of the war and post-war times that we all have long known about. Rather it is the fact that human beings, who for decades did not even feel that they had experienced awful things in their childhood and youth, only now at an old age are beginning to understand to what extent their lives were stamped by early losses and threats, causing various kinds of trauma (Bode 2004:291). This is what Alexander Mitscherlich labelled the 'inability to mourn' (Mitscherlich \& Mitscherlich 1975, passim). 
Reconstructing the early years of their lives during war times, however, these people - only since the last decade of the 20th century - very often undergo a remarkable change: Having looked at the burdens - including their cause and effect they had been carrying with them for a long time, they feel relieved and released. And psychologically speaking, this is of the highest importance. For without 'remembrance work' and the endeavour of looking thoroughly into one's biography, there is no sense of continuity in one's life and thus there will develop no positive identity (Bode 2004:292).

Identities can only be built if humans succeed in integrating even fatal experiences into their self-understandings. Theologically speaking, it is a question of self-love according to the Old and New Testament message (Lv 19:18, Mt 22:39, Gl 5:14). Moreover, it is a matter of being accepted unconditionally, namely by God ( $\operatorname{Rm} 15: 7)$, that is, from a Christian point of view, that the right to exist is granted to a person by God in spite of her or his deficiencies.

\section{The post-war generation of the Second World War}

In the post-war generation, to those born in the 1950s like myself, at a certain moment the question arose as to what extent parents had been involved in the atrocities of the Nazi regime and the acts of war, not to mention the possibility of knowledge, involvement or even cooperation in the system of concentration camps and extermination, not only of the Jews.

As adults, children remember their fathers who participated in World War II and even collaborated with the NS system, with due ambivalence: Meckel (1980:4) puts it this way: 'The man I knew was only a part of that other man whom nobody knew'. And Dörte von Westernhagen (1987:11) writes: 'We did not recognize that the fathers were already living on within ourselves, in a hidden way which was difficult to see through'. Bruhns (2004:8), finally, remarks: 'I want to understand how that came into existence what so deeply affected my generation, the generation of those born later'.

Post-Second World War children oftentimes portray their parents as not very emotional; problems in the children's sentiments were preferred not to be acknowledged as such. Instead of consolation, only placation was granted (Bode 2011:21). Many of them grew up in misery, surrounded by adults who were deranged and burdened, and underwent a strict upbringing. The fear that the father might have been a Nazi was widespread in the first years after the war. However, the climate was rather nebulous; details could not be perceived clearly (Bode 2011:236, cf. 259-275). And many cruel and barbarous deeds and events were simply covered up (Bode 2011:260). Many of my generation felt something like 'vicarious guilt' (Bode2011:137-139). It is no contradiction, however, that some were forced to discover that their fathers not only fought for the Nazis, but fought as Nazis (Bode 2011:169). Therefore they felt obliged to somehow compensate for what their fathers had committed.
From a historical point of view, there can be no doubt that the Wehrmacht [armed forces] was part and parcel of a criminal system (Bode 2011:179-193). Of course, soldiers were not in the position to identify themselves as perpetrators; rather they would claim to only have done their 'duty'. This can be explained by the fact that war in any case creates a new framework for exerting acts of violence. However, in large part, the German population knew that the Jews (and others) were being deported, and at least had a premonition of the extinction that those people would have to face. Mass executions could not remain hidden to the troops.

Others, a minority however, saw, especially from a pious point of view, that with the anti-Jewish pogroms of 1938 the war that began only 1 year later was already lost (Bode 2011:226). These people identified the Nazi war as sin right from the outset (Bode 2011:230).

On the other hand those who came back from war, especially those prisoners of war who returned only years later, were deeply traumatised by the experience of violence, comrades being killed and other terrible memories (Bode 2011:97-99). This applies for example to my father, who was captured by the US on Easter morning, 1945, at the age of 19 and taken to California for 1 year but then sent to the French to work in the coal mines of northern France; on coming home he found that his parents had died in spring 1945, and his elder brother had been killed in action in Russia.

The solution to these experiences was often to simply cut off the past: We too, were victims. The memories of their own captivity suppressed the reminiscence of what happened in the times of war: 'That was what we went through, now let us look ahead!' (Bode 2011:110). Or, put differently: 'I do know a whole lot, but I do not talk about it' (Bode 2011:145). However, in their everyday lives, these fathers showed behaviour by which they tried to compensate for their own lack of appreciation, which at times was similar to a selfdegradation, behaviour like outrage, a sense of superiority over others, addiction.

Only at a later stage were the children of the World War II soldiers able to realise and acknowledge to what degree their fathers had been damaged mentally and emotionally, and how influential a climate of concealment and silence covered their childhood (Bode 2011:157f.). Regularly they had reacted with doubt, anger, aggressive behaviour and hate to the stories of the previous generation. However, finally they had to agree that you simply cannot get rid of your parents (Bode 2011:176). In contrast, one can detect a phenomenon that may be labelled a 'trans-generation transmission' of wrongdoing and wrong conduct. For trying to do each and every thing in a totally different manner than the parents does not necessarily lead to freedom from the environmental conditioning or family-bound imprint one has undergone quite the opposite!

Traumatisms may be passed on to the next generation. The same holds true, however, even if memories have been 
suppressed, with experiences of one's own wrongdoing (Hammerich et al. 2009:27-46). In the Bible this phenomenon is addressed in a metaphor, 'The parents eat sour grapes, and the children's teeth are set on edge' (Ez 18:2), and is more explicitly addressed by the apostle Paul:

For just as through the disobedience of the one man the many were made sinners, so also through the obedience of the one man the many will be made righteous. ( $\mathrm{Rm}$ 5:17)

\section{The children of the post-war generation - 'Grandchildren' of World War II}

It is to be noticed that even the children of parents who belonged to the post-war generation carried - and still carry - 'landscapes with burn marks' within themselves (Bode 2012:29). It is no surprise, in any case, that the major part of the population wants to let rest the history of the Nazi times and World War II: 'We do not want to think of these things any more. We know all about the facts'. What is lacking though is a sense for the aftermath of those events now 70 to 85 years ago. However, there are still aftershocks lingering today.

The former bishop of the United Evangelical-Lutheran Church in Germany, Hans Christian Knuth, a conservative theologian, has expressed it this way (Bode 2012):

For us, as post-war children, it was a matter of breaking the silence about guilt and failures that was [sic]weighing on us. [...] But the silence about our own fears and sorrows when we were children was not yet broken. [...] That we as war children were victims, too, did not occur to us. (p. 177)

The negative energies resulting from these traumata are transferred to the next generation, shadows that are passed on only to cloud the lives of children and grandchildren (Bode 2012:170f.).

This is, as psychologists report, expressed in what they call a 'diffuse identity'. These people feel unbalanced or dissonant within themselves (Bode 2012:34). The children may come to comprehend that their parents - the mothers, in particular were victims (Bode 2012:150), but as such, mothers, particularly if they wished to suppress the memories of fatal incidents, and children alike lacked abilities that healthy people do have: the feeling of security, trust in life, confidence, emotional awareness, empathy (Bode 2012:273, 287). Therefore, the parents were not able to give solace, although and whenever a word of consolation ought to have been given (Bode 2012:156). In contrast they were influenced by experiences that had not been attended to by their parents (Bode 2012:162, cf. 219-221).

Children oftentimes are inevitably dependent on even hidden traumatisms their parents, albeit unconsciously, suffer from; they cannot avoid being connected to and influenced by their parents' unsaid, yet implied emotional distress that still has an impact across the alternation of generations (Barbre 2015:xi-xvii).

\section{Repentance as the core attitude of the Christian church}

From theology, history and psychology we may learn that unacknowledged guilt will 'take revenge'. A person who does not recognise his or her wrongdoing in order to perceive, confess and in the future avoid it will be trapped by this very fault again, and unexpectedly so. Unidentified wrongdoing will most probably close in on us and determine our thinking and our actions in a greatly disadvantageous way.

Psychologists, in such cases, speak about 'transference', as Moré (2013) states:

The psychoanalytic term of transference not only describes an ongoing event between analyst and client in therapeutic processes but points to a formative phenomenon in all human relationships. Those transmissions have great influence on intergenerational relations in a good or bad sense. Freud called this kind of transmission an emotional heritage. The questions which are raised concern the differences between generations and what connects them together as well as the role of conscious and unconscious transmissions in this process. First the mechanisms of unconscious transmissions of experiences from the parents to their children are described. Afterwards the effects of the unwilling transmission of (extreme) traumata or involvements into guilt to victims' or perpetrators' offspring are discussed. (p. 1)

Theologically speaking, descendants are burdened with the consequences of their parents' or forbears' demeanour; this is the meaning of an often-misunderstood verse in the book of Deuteronomy (34:6-7):

The Lord, the Lord, the compassionate and gracious God, slow to anger, abounding in love and faithfulness, maintaining love to thousands, and forgiving wickedness, rebellion and sin. Yet he does not leave the guilty unpunished; he punishes the children and their children for the sin of the parents to the third and fourth generation.

This is more a 'formula of mercy' (Gnadenformel) (Spieckermann 2001:9-14, cf. Spieckermann 2008:3-16) than an execration.

While desiring to remain faithful to ourselves and the biblicalreformation witness, we have to employ the term 'guilt'. To be guilty, to be guilty of something, to be guilty towards someone: these refer to relationships or dealings, which are judged according to a standard of success and failure. Guilt implies that one either has or lacks an obligation in relationship to others. 'Whoever is guilty towards another, damages', or falls short of, 'what their relationship is supposed to be', whether that 'other' is a fellow human being or God. Therefore, investigation and understanding of guilt and consciousness means nothing other than recognising that we have not met the goal to which we were meant to direct ourselves, and particularly so according to God's will and command.

In confession and repentance we are placed before God and are asked what our condition is before him. Simultaneously, 
a judgement is rendered upon us when we wish to master our life with our own powers. In God's eyes, the problem is our conviction that we are our own masters and that we control the world, while in reality we orbit only around ourselves. Thus, all people are subject to the judgement that their lives are a failure when and because they look to themselves. ${ }^{3}$ We must recognise this and confess 'that we neither have nor do what we ought' (Kolb \& Wengert 2000:477). Thus, in our confrontation with the holy God, we realise that we have fallen short of the goal of our existence.

In this moment we are called to self-recognition, to an unadorned, unvarnished and unsparing regard of our real condition. However, the measures used by such selfassessment, which are grounded in faith, do not lie within us but in God's ordinance. Hence, the insight and confession arises that I am none other than the one exposed before God in the light of his ordinance and according to the measure of his command. Such a confession is a 'yes' to my 'no' and conversely a 'no' to my 'yes'. I must affirm that I do not measure up to what God wants of me and at the same time deny that such a 'not measuring up' is in order.

One of Luther's fundamental insights is that those who realise the untenable state of their being and the abysmal condition of their lives recognise that they can provide neither a foothold nor a foundation for their lives. They rely on and hold fast to the fact that help comes from somewhere else, specifically from God. 'For this is the essence of a genuinely Christian life, to acknowledge that we are sinners and to pray for grace' (Kolb \& Wengert 2000:477). This desperately desired affirmation of divine aid comes from the Gospel. For in absolution God promises us that when we reach the end of our resources he opens new possibilities to us. Exactly at the point where we believe escape is impossible, God lets us know that he provides a new way for us. The fundamental insight of Martin Luther was that 'this repentance stays with the Christian unto death' (Kolb \& Wengert 2000:318 [SA III 3]). This insight understands the entire life of a Christian as a process led by the Holy Spirit and aiming at final salvation. The Spirit 'works to make the man truly pure and holy' (Kolb \& Wengert 2000:318 [SA III 3]). Here Luther has in mind a procedural event that is founded in a theology of baptism.

Repentance is therefore 'nothing other than a return and stepping towards baptism' (Kolb \& Wengert 2000:466 [LC IV 79]; Peters 1993:94-100; Wenz 1997:118-123), 'nothing other ... than baptism' (Kolb \& Wengert 2000:465 [LC IV 74]), indeed, on a daily basis. On the other hand, Luther can also emphasise the progressive aspect of baptism, which connects to the idea of sanctification as it was developed in the exposition of the third article of the creed (Lohse 1995:278280; Wenz 1996:611-613). Regarding the basis set in baptism, it states: 'started once and continuously proceeding in it' (Kolb \& Wengert 2000:465 [LC IV 65]), or, in the nexus of the

3.This is really what it means to begin true repentance. Here a person must listen to judgment such as this: 'You are of no account ... here no one is righteous' (eds. Kolb \& judgment such as this: 'You are
Wengert 2000:312 [SA III 3]). aspects of the return into baptism and the proceeding forth from this baptism, it states: 'This is what it means truly to plunge into baptism and daily to come forth again' (Kolb \& Wengert 2000:465 [LC IV 71]). In this daily process of return to the founding date of Christian existence lies the prerequisite for all continuation forward on the path of Christian faith and life. 'The new life should be lived so that it continually increases and proceeds forward' (Kolb \& Wengert 2000:469 [LC V 24]). This is no less than the catechetical exposition on Martin Luther's first of the 95 Theses: 'When our Lord and Master Jesus Christ said, "Repent" [Mt 4:17], he willed the entire life of believers to be one of repentance' (Grimm \& Lehmann 1957:25).

What is usually applied to the life and conduct of individual Christians may be suitable for the life of the church as well. For according to Martin Luther, the church is 'maxima peccatrix' - 'the biggest sinner of all'. The Wittenberg Reformation had in mind to recall the Roman Church to the biblical truths as summarised in the Augsburg Confession:

As can be seen, there is nothing here that departs from the Scriptures or the catholic church, or from the Roman church, insofar as we can tell from its writers. Because this is so, those who claim that our people are to be regarded as heretics judge too harshly. The entire dissension concerns a few specific abuses which have crept into the churches without any proper authority. (Kolb \& Wengert 2000:59 [AC 'Conclusion of Part One'])

This said, Melanchthon and the Augsburg confessors issued a call for repentance to the adherents of the papal church. For with deep-rooted certitude, Melanchthon can say that 'just as the church has the promise that it will always have the Holy Spirit, so it also has the warning that there will be ungodly teachers and wolves' (Kolb \& Wengert 2000:177 [Ap VII/VIII 22]). The church, as it exists under the circumstances of this time and age, is a 'corpus permixtum', a 'mixed body' consisting of 'saints who truly believe the Gospel of Christ' and at the same time of 'many hypocrites and wicked people who are mixed in with these' (Kolb \& Wengert:178 [Ap VII/VIII 28]).

For the church to manage its contemporaneity in a critical manner therefore means, first and foremost, that it becomes aware of its own interwovenness with the times in which it exists. It will therefore first take to heart that which it voices in a critical manner to the world outside itself if it wants to ensure the credibility of its declaration and message. Thus the church itself will always have to answer to the question as to whether and to what extent the church, together with its members, holds itself to those divine standards that it feels compelled to address.

As we have seen, individual trauma and collective types of trauma have many an aspect in common. What can be observed in personal biographies may as well be seen in corporate entities. There can be no doubt that the history of South Africa, including the history of the Lutheran church in Southern Africa and the Free Evangelical Synod in South Africa, is burdened with injustice, violence and violations 
of human dignity, even among Christians. The theological confrontation with the conditions of the Mission of Lutheran Churches, the Free Evangelical-Lutheran Synod in South Africa, the Lutheran Church in Southern Africa and the Independent Evangelical-Lutheran Church in Germany has only just begun: Now critical and self-critical voices of South African Christians with their assessment of the mission history of their continent are also becoming more clearly audible (Böhmer 2016, passim).

That is why those churches in 2012 launched the Trilateral Commission on Apartheid, which was commissioned to do thorough research. This commission has been - and still is attempting to perceive traumatic experiences in the church history of South Africa. What we are doing is facing facts and feelings occurring in the last decades of the history of the confessional Lutheran churches in southern Africa that were and still are perceived as hurtful and harmful to individual church members but also to congregations and possibly to the relationship between the various church bodies in the history of confessional Lutheran churches in South Africa and Botswana in particular.

We may learn about the chances and challenges to such a process in recent practical-theological research on 'remembering violence', which is about:

exploring acts of remembrance which are respectful to the dead and which take the uncontrollable, at times haunting, past into account, while probing how life might flourish - at least in fragmentary ways - in the aftermath of violence. (Bieler 2011:39)

She does not exclude the fact that 'acts of memory can provoke' even 'negative effects', that is to say, they 'might produce the opposite of what they claim to do' (Bieler 2011:40). This might be a peril that may threaten the process we are trying to promote, thus evoking reluctance on the side of some of the recipients of the results we will present: 'We can recognize waves of memory practices and at the same time various forms of resistance to them' (Bieler 2011:42). I would like to mention this fact only because we have to be aware of this endangerment. It is important to perceive that ' $[c]$ ollective memory $[\ldots]$ becomes a contested terrain that produces multiple streams of remembering' (Bieler 2011:46). ${ }^{4}$ It is important to recognise that the field in which collective remembering happens is, in many contexts, not a peaceful or homogeneous one. It is rather highly disputed. This is, to my conviction, the very situation this commission and the churches that have commissioned us find themselves in if we look at the addresses of our results.

In order to deal carefully and cautiously with our task, we have to notice that:

[o]ftentimes, remembering in the aftermath of collective violence takes on the form of trauma. Trauma refers to an engagement

\footnotetext{
4.The author then lists various 'mnemonic media and acts of mediating the past' (p. 46) among them the following. 'affective media' (like religious festivals) '[a]esthetic expressive media' (like monuments, works of art, etc.); ' $[i]$ nstrumental cognitive media' (like the creation of historical archives, historiography, etc.) cognitive media' (like the creation of historical archives, historiography, etc.);
' $[p]$ olitical moral media' (like punishment, amnesty, reparations, a Truth and Reconciliation Commission) (p. 47).
}

with the past in the aftermath of an event of overwhelming violence in which the actual horrific event cannot be recalled and cannot be brought into consciousness.

That is to say: 'The traumatic event escapes accessibility' (Bieler 2011:50). I am deeply convinced that this holds true for many of the Lutheran Church in Southern Africa congregants; it would be helpful on the road to reconciliation if on the side of Free Evangelical-Lutheran Synod in South Africa and of Selbständige Evangelisch-Lutherische Kirche/ Mission of Lutheran Churches some kind of acknowledgement to these effects of the apartheid times, even in the interchurch relations, could be manifested. This would be a very important step because we know that:

in many societies [...] the passing on of trauma through various generations happens in multiple ways. The very events that produced traumatizing effects return in new shapes and are repeated in new forms of violence. (Bieler 2011:51)

It might be interesting to follow a suggestion to apply liturgical forms that the churches are well acquainted with as paradigms of overcoming the traumatic remembrance of violent events. Thus we might come to understand:

the Eucharist as a focal rite within the Christian faith, in which we are drawn into a story of divine redemption, which has at its heart the transformation of violence. (Bieler 2011:53)

This is, from a Lutheran point of view, not everything that ought to be said about the Lord's Supper, but it points to crucial aspects of the Sacrament of the Altar. For indeed, in the celebration of the Eucharist, 'the tortured Christ' makes himself present 'as the Resurrected One', thereby holding together 'the marks of vulnerability and violence' and their 'transformation' into new, eternal life at the same time (Bieler 2011:53). And communicating what he, our crucified and risen Lord, has sacrificed to redeem the whole world, in the Sacrament of the Altar, he reincorporates the penitent sinner into his body.

There can be no doubt that the church is obliged to confess and admit to many a transgression against divine standards, both on behalf of its members and also of itself in its aggregate - in general and in particular. However, it is exactly this stance that will not affect its credibility but rather strengthen it, provided that it is spoken not from a position of hubris but from one of befitting humility and informed by the knowledge of its own failings with regards to the divine standards when it speaks from its conscience in this manner. In that case a confession of guilt spoken by the church repentance! - does have its place and is meaningful. For here, too, applies Luther's thesis: 'The true treasure of the church is the most holy gospel of the glory and grace of God' (Grimm \& Lehmann 1957:31).

\section{The challenge and the mission of the church}

It has always been seductive to Christians - and to church leaders in particular - to see the church as a culturally, 
politically, morally influential and even predominant factor or institution in this world. That tempting dream, in some realms of Christianity still lingering on, belongs most intimately to the imperial ideology and ecclesiastical enthusiasm of the Constantinian era.

Nonetheless, it remains the task of the church to proclaim the 'righteous, unchanging will of God' (Kolb \& Wengert 2000:584 [FC SD V 17]) for his world and its population, in a manner that is relevant to today. The church is thus obligated to be critical of her contemporary setting. Contemporary life also affects the church and her members. One cannot deny that the church is influenced and affected by worldly, societal 'trends' and tendencies. These movements do not only find expression 'outside and around' the church but also creep into the church. Yet the church demonstrates that it is contemporary when it resists current developments of which it cannot approve.

With regard to the task of the historical revision of the joint history of the Mission of Lutheran Churches, the Free Evangelical-Lutheran Synod in South Africa, the Lutheran Church in Southern Africa and the Independent EvangelicalLutheran Church in Germany, therefore, probing questions must be asked, such as:

What was the relationship between the doctrine of Holy Scripture and de facto exegesis or proclamation in the respective churches or congregations like? - How was the confessional position of the Lutheran churches related to their acts of confessing and testifying to the Word of God and the Lutheran Confessions? - In which way can the assessment between the concept of the 'order of creation' and salvation be described? - Is it conceivable that the Lutheran concept of the 'order of creation' and the doctrine of the 'two kingdoms' was mixed up, or at least augmented with politic-religious ideas that originated from a more or less Calvinist view? - What does it mean that since 1967, the LCSA was regarded to be independent in its self-governance and decisions? - What does it mean that at the same time, the Lutherische Kirchenmission [Mission of Lutheran Curches] was still working in South Africa, having its own structures, budget, congregations? - How did church leaders on the side of LCSA, FELSiSA, and MLC react to apartheid legislation (and legislation leading to apartheid prior to the official establishment of the apartheid system)? - Which was the relationship between pastoral care, advocacy of the oppressed, theological protest (according to Ac 5:19), and political adjustment to the apartheid system? - How were/are scriptural principles and the influences of the so-called 'spirit of the time' related to one another? - Did the distinction of spirits have a place in those years? - In which way was the doctrine of the two kingdoms utilised to whitewash obvious injustice? - According to which principles were decisions made not to interfere with the South African state and its security forces? - Will the respective pastors, elders, congregants, church leaders who were responsible in those days be able to gain insight into personal failure, structural imbalances, incorrect and wrong decisions? - What was done to apply the Word of God to this time and world? - In which way was the civil/political use of the Law of God (in the Lutheran understanding) exercised in statements, proclamation, and instruction of the confessional Lutheran churches? - This list of questions is by no means exhaustive (Klän 2012:73).
However, before the church, or a given church through its representatives, speaks to the situation of its time, the church must first speak to herself, turn to herself and permit herself to see that her message concerning the situation of mankind and the world is also her own diagnosis. It is not that the church 'asserts herself' wherever God allegedly authorises her to; rather, it simply proclaims 'what the point is' to the world to which it is directed: Mankind stands before God and can neither abolish nor create this existence, nor run away from the judgement that humans are, as they are, lacking in their state of existence before God (Wenz 1997:73).

For me, it is intriguing to see the way the doctrine of justification may be applied to the question of overcoming violent experiences:

Mutual religious commitment gravitates toward the faith of justification by grace alone - both as a set of inner convictions and attitudes and as an outward mode of social behavior. The gift of God's grace can neither be earned nor justified nor sufficiently and conclusively matched by human efforts. This promise is encountered and realized in [...] moments of gratitude - dense moments of bliss and abundance. In such moments, people come to look upon their life with a feeling of thankfulness and appreciation. [...] The communication of the Gospel in sermon and liturgy, pastoral care, [...] may create spaces for this existential experience to happen. (Gutmann 2011:140)

We would be well advised, I suppose, to apply the implications of these basic biblical-Lutheran theological standards to the configuration of our interchurch relations.

On the background of even harmful experiences, those who identify themselves as victims of serious disregard, and those who may become aware of their contributory negligence to such affects - both of which will certainly be a bitter perception - as Christians may learn that a new, God-given identity can be restored to them, because the brokenhearted may be healed and their wounds be bound up. For God in his profound compassion confers to these human beings such a new identity.

\section{Acknowledgements Competing interests}

The author declares that he has no financial or personal relationships which may have inappropriately influenced him in writing this article.

\section{References}

Barbre, C., 2015, 'Foreword', in M. O'Loughlin (ed.), The ethics of remembering and the consequences of forgetting: Essays on trauma, history, and memory (New Imago), pp. xi-xvii, Roman \& Littlefield, Lanham, MD.

Bayer, O., 2002, 'Towards a theology of lament', in D. Whitford (ed.), Caritas et reformatio: Essays on church and society in honor of Carter Lindberg, Concordia Publishing House, Saint Louis, MI.

Bayer, O., 2005, 'Mit Luther in der Gegenwart: Die diagnostische Kraft reformatorischer Theologie', in N. Slenczka \& W. Sparn (eds.), Luthers erben: Studien zur Rezeptionsgeschichte der reformatorischen Theologie. Festschrift Jörg Baur, pp. 297-310, Mohr Siebeck, Tübingen.

Bieler, A., 2011, 'Remembering violence: Practical theological considerations', in A. Bieler, C. Bingel \& H.M. Gutmann (eds.), After violence: Religion, trauma and reconciliation, pp. 40-60, Evangelische Verlagsanstalt, Leipzig. 
Bode, S., 2004, Die vergessene generation: Die kriegskinder brechen ihr schweigen, Klett-Cotta, Stuttgart.

Bode, S., 2011, Nachkriegskinder: Die 1950er jahrgänge und ihre soldatenväter, KlettCotta, Stuttgart.

Bode, S., 2012, Kriegsenkel: Die erben der vergessenen generation, Klett-Cotta, Stuttgart.

Böhmer, K.E., 2016, August hardeland and the rheinische and hermannsburger mission in Borneo and Southern Africa (1839-1879). The history of a paradigm shift and its impact on South African Lutheran churches, 18th edn., Oberursele Hefte, Ergänzungsband Ruprecht, Göttingen.

Bruhns, W., 2004, Meines Vaters land: Geschichte einer deutschen Familie, Econ, München.

Dingel, I., 2014, Die Bekenntnisschriften der evangelisch-lutherischen Kirche, Vandenhoeck \& Ruprecht, Göttingen.

Duran, E. \& Duran, B., 1995, Native American Postcolonial Psychology, SUNY Press, Albany.

Gobodo-Madikizela, P. \& Van der Merwe, C.N., 2009, Memory, narrative and forgiveness: Perspectives on the unfinished journeys of the past, Cambridge Scholar Publishing, Newcastle upon Tyne.

Grimm, H.J. \& Lehmann, H.T. (eds.), 1957, Luther's works American edition: Career of the reformer, vol. 31, Fortress Press, Philadelphia, PA.

Gutmann, H.M., 2011, 'After violence: Narratives of grace in the midst of trauma', in A. Bieler, C. Bingel \& H.M. Gutmann (eds.), After violence: Religion, trauma and reconciliation, pp. 40-60, Evangelische Verlagsanstalt, Leipzig.

Hammerich, B. et. al., 2009, 'Handing down the Holocaust in Germany: A reflection on the dialogue between second-generation descendants of perpetrators and survivors', in P. Gobodo \& M.C. van der Merwe (eds.), pp. 27-46.

Klän, W., 2012, 'Unavoidably contemporary. Theological, historical and methodological aspects in dealing with the recent history of the confessional Lutheran churche in Southern Africa', in W. Klän, G. da Silva (eds.), Mission und apartheid. ein unentrinnbares erbe und seine aufarbeitung durch lutherische kirchen in südlichen Afrika, 12th edn., pp. 65-76, Oberurseler Hefte. Ergänzungsband Ruprecht, Göttingen.

Kolb, R., 2010, 'Deus revelatus - Homo revelatus, Luthers theologia crucis für das 21 Jahrhundert', Oberurseler Hefte 40, 13-34.

Kolb, R., 2012, Luther and the stories of God: Biblical narratives as a foundation for Christian living, Baker Academic, Grand Rapids, MI.

Kolb, R. \& Arand, C.P., 2008, The genius of Luther's theology: A Wittenberg way of thinking for the contemporary church, Baker Academic, Grand Rapids, MI.

Kolb, R. \& Wengert, T.J., 2000, The book of concord: The confessions of the evangelical lutheran church, Fortress Press, Minneapolis, MN.

Lohse, H., 1995, Luthers theologie in ihrer historischen entwicklung und in ihrem systematischen Zusammenhang, Vandenhoeck \& Ruprecht, Göttingen.

Moré, A., 2013, 'Die unbewusste Weitergabe von Traumata und Schuldverstrickungen an nachfolgende Generationen', Journal für Psychologie 21, viewed 18 August 2018, from https://www.journal-fuer-psychologie.de/index.php/jfp/article/view/268/310
Meckel, C., 1980, Suchbild: Über meinem Vater, Claasen, Berlin

Mitscherlich, A. \& Mitscherlich, M., 1975, The inability to mourn: Principles of collective behaviour, Grove Press/Random House, New York.

O'Loughlin, M. (ed.), 2015, The ethics of remembering and the consequences of forgetting: Essays on trauma, history, and memory (New Imago), Roman \& Littlefield, Lanham, MD.

Peters, A., 1993, Kommentar zu luthers katechismen, Bd. 4: Die taufe, das abendmahl, Vandenhoeck \& Ruprecht, Göttingen.

Peters, A., 1994, Kommentar zu Luthers Katechismen, Bd. 5: Beichte, Haustafel, Traubüchlein, Taufbüchlein, Vandenhoeck \& Ruprecht, Göttingen.

Pless, J., 2013, Martin Luther. Preacher of the cross. A study of Luther's pastora theology, Concordia Publishing House, Saint Louis, MI.

Rolf, S., 2003, Vom Sinn zum Trost: Überlegungen zur Seelsorge im Horizont einer relationalen Ontologie, LIT Verlag, Münster.

Scaer, D., 1983, 'The concept of anfechtung in Luther's thought', Concordia Theological Quarterly 47, 15-30.

Schwab, G., 2010, Haunting legacies: Violent Histories and transgenerational trauma Columbia University Press, New York.

Sotero, M.A., 2006, 'Conceptual model of historical trauma: Implications for public health practice and research', Journal of Health Disparities Research and Practice 1, 93-108, Las Vegas, NV, viewed 18 August 2018, from https://www.ncbi.nlm. nih.gov/books/NBK207192/\#section1.s1

Spieckermann, H., 2001, 'Barmherzig und gnädig ist der Herr', in Ders., Gottes Liebe zu Israel. Studien zur Theologie des Alten Testaments (FAT 33), pp. 1-18, JCB Moh 2001, Tübingen, 3-19; = ZAW 102.

Spieckermann, H., 2008, 'Wrath and mercy as crucial terms of theological hermeneutics', in R.G. Kratz \& H. Spieckermann (eds.), Divine wrath and divine mercy in the world of antiquity (FAT II /33), pp. 3-16, JCB Mohr, Tübingen.

Substance Abuse and Mental Health Services Administration, 2014, SAMHSA's concept of trauma and guidance for a trauma-informed approach, US Department of Health and Human Services, Substance Abuse and Mental Health Services Administration, Office of Policy, Planning and Innovation.

Tappert, T., 1955, Luther's letters of spiritual counsel, Westminster Press, Philadelphia, PA.

Volkan, V.D., 2009, 'The next chapter. Consequences of societal trauma', in P. GobodoMadikizela \& C.N. Van der Merwe (eds.), Memory narrative and forgiveness: Perspectives on the unfinished journeys of the past, pp. 1-26, Cambridge Scholar Publishing, Newcastle upon Tyne.

Wenz, G., 1996, Theologie der Bekenntnisschriften der evangelisch-lutherischen Kirche, vol. 2, Walter de Gruyter, Berlin.

Wenz, G., 1997, Einführung in die evangelische Sakramentenlehre, Wissenschaftliche Buchgesellschaft, Darmstadt.

Westernhagen, D.V., 1987, Die Kinder der Täter: Das dritte Reich und die Generation danach, Kösel, München. 